Ivica Pervan*

UDK 657.3:336.76>(497.5)"2005/2009"

Josip Arnerić**

Preliminary paper

Mario Malčak ${ }^{* *}$

Prethodno priopćenje

\title{
THE INFORMATION CONTENT OF EARNINGS AND OPERATING CASH FLOWS FROM ANNUAL REPORT - ANALYSIS FOR CROATIAN LISTED COMPANIES
}

\begin{abstract}
The main purpose of this research was to test the content of accounting information (earnings and operating cash flow) in the context of investors' decisions at capital markets. The research is based on event study approach where return volatility index $R V I_{i t}$ is used as measure of market reaction in the period of 10 days before and after publishing the accounting information. The research was done on the sample of companies from CROBEX 10, i.e. on the sample of 10 most traded companies from the Zagreb Stock Exchange in the period 2005-2009. As a general conclusion we can point out that accounting information (earnings and operating cash flow) from annual report has information content since the market reacts to published information with abnormal returns.
\end{abstract}

Key words: earnings, operating cash flows, information content, stock returns

\section{INTRODUCTION}

According to the modern accounting frameworks of FASB \& IASB (IASB, 2008; Lewis, Pendrill, 2004) accounting information should be useful for capital market investors (among other users). After the early studies in 1960-ies many researchers from different countries have tested the information content of accounting information on the capital markets. Since this kind of research is almost nonexistent in Croatia we decided to test the information content of two basic accounting performance measures from annual report (earnings and operating cash-flows). Although this kind of research is pretty "classical" in free market economies with developed capital markets it still represents a very interesting research topic for an emerging market country like Croatia. Namely, Croatia is still developing institutions of free market economy by implementing reforms and accepting modern standards in different areas. One of the areas of such reform is the area of financial reporting where Croatian listed companies since 1993 implement IASB standards (IAS/IFRS). Although the implementation of IFRSs should result with high quality accounting information the practical implementation of IFRSs in Croatia is still rather problematic. Namely, recent research (Pervan, 2009) has shown that Croatian regulatory framework for the listed companies for a long period (1993-2009) did not require publication of the following important annual report elements: notes, accounting policies, segment information, related parties transaction, auditor report, etc. Another research (Pervan, 2006) that addressed the issue of Croatian listed companies' voluntary disclosure has also

\footnotetext{
* Associate professor, Ekonomski fakultet Split, Matice hrvatske 31, 21000 Split, ivica.pervan@efst.hr

** Assistant, Ekonomski fakultet Split, Matice hrvatske 31, 21000 Split, jarneric@efst.hr

*** Mag.oec, UHY HB EKONOM, Hrvatske mornarice 1H, 21000 Split, mario@antenazadar.hr
} 
discovered that Croatian listed companies on average are not very transparent in terms of voluntary Internet reporting.

Taken together findings from the previous research on financial reporting of listed companies in Croatia here we must observe that capital market investors in Croatia are faced with limited scope annual financial reports. Such financial reporting environment might put into question the trust of investors in quality of published information and limit the practical use of accounting information in investment decisions. Furthermore, according to financial reporting clusters Croatia belongs to European continental model since accounting information is primarily provided for the tax authorities. Vast majority of companies (even publicly traded) finance operations and investments trough the bank loans. IPOs are still very rare and during the last twenty years only a few private companies went public trough IPO. Capital market is mainly secondary market where investors trade the stocks of previously privatized state owned companies.

From the daily media, specialized financial journals and analyst interviews we can often hear that Croatian capital market is undeveloped since it is shallow, pretty volatile and incorporates a significant role of insider trading. The limited content of annual reports, taken together with undeveloped capital market might put into question the information content of annual accounting information. Such business environment in Croatia was a main stimulus for this study. The study follows the classical approach defined by the early papers, but as a methodological contribution of the study we could point out the usage of daily variance instead of constant variance when calculating abnormal returns. As period of analysis we decided to use the period from 2005 to 2009. During the period of analysis the Croatian economy and capital market were facing years of strong growth, fall and stagnation. Longer data series have allowed us to analyze capital markets reaction on accounting information announcements in different stages of economy cycle and general economic expectations.

The paper is organized in the way that after introduction we have presented early and recent research on the issue of information content of accounting information announcement. After that in the third part of the paper we have described the research methodology, including data sources and equations. Research findings are presented in the fourth chapter, which is followed by the concluding remarks.

\section{REVIEW OF LITERATURE}

Since the early work of Ball \& Brown and Beaver in 1968 the analysis of relationship between accounting earnings announcement and reaction of capital markets has attracted considerable attention. The interest for this issue is legitimate, given the generally accepted modern financial reporting conceptual frameworks which point out that accounting figures are aimed at providing investors with relevant information for their investment decisions. Regarding the capital markets accounting information is used in order to facilitate the prediction of firms' future cash flows, risk and returns. The main aim of early researches was testing the usefulness of accounting information for the investors. This kind of research starts from the assumption which states that if capital markets are efficient, stock prices should reflect quickly and fully any newly publicly released information (including published accounting information).

Beaver (1968) made one of the first empirical studies examining the information content of annual earnings. His study empirically examined the extent to which common stock investors perceive annual earnings to possess informational content. Beaver defined information as a change in expectations about the outcome of an event. Within the context of his study, a firm's earnings and operating cash flow announcement is said to have information content if its announcement leads to a change in investors' assessments of the probability 
distribution of future returns (or prices), such that there is a change in equilibrium value of the current market price. His research showed that the stock prices are on average $67 \%$ higher in the announcement week than the average price for all other weeks. Research showed that the stock market reacts significantly on financial statements announcements, which leads to conclusion that financial results of the firm's have significant information content.

The main aim of Ball and Brown's (1968) study was to show the existence of the association between the abnormal returns of a firm's securities and the announcement of annual accounting earnings. Based on the firm's reported earnings, a company was classified as reporting good (bad) news if reported earnings were above (below) predicted earnings. Through their study they managed to show that good (bad) news firms enjoyed, on average, abnormally positive (negative) returns. Furthermore, the study showed that $80 \%$ to $85 \%$ of the abnormal market return occurred prior to the publication of the annual report.

After the pioneering work of Beaver and Ball \& Brown later studies use different accounting variables, different financial statements, different forecast models for earnings, different market variables in order to test information content of accounting information (White et. al. 1997). Later studies, with usage of more sophisticated methodologies and more detailed market data, mainly confirmed the findings from early studies that accounting number have information content for investors. Thus for example, Morse (1981) used daily data on abnormal returns and discovered that significant price reaction exists one day before and one day after earnings announcement in the Wall Street Journal. Patell and Wolfson (1984) due to information technology advances put research focus on intraday reaction. Namely, Dow-Jones newswire releases earnings information even before it is published in the Wall Street Journal. Intraday analysis has revealed that major portion of market reaction happened within the first two hours after earnings announcement trough Dow-Jones newswire.

Research for the Cyprus Stock Market on publication of earnings and cash flows was done by Vafeas et al. (1998). The Cyprus Stock Market at that time was characterized by low liquidity and no financial newspapers or special financial web pages. Researches took into consideration all stocks in period of 10 years and they managed to prove that operating cash flow had the same information content as earnings. Also they discovered that earnings had more content when they were positive, for bigger companies, and in the later years of the analyzed 10 years period.

Gajewski and Quere (2001) analyzed the data from the Paris Stock Exchange and they wanted to prove the existence of information content of earnings for different financial statements (annually, semi-annually and quarterly). Empirical findings indicated that semiannual earnings announcements had less information value than yearly earnings announcements. Authors also proved that second and forth quarterly report caused bigger reaction than reports for first and third quarter.

A cross-country analysis was made by DeFond et al. (2007) using data from over 50,000 annual earnings announcements in 26 countries. The study found that annual earnings announcements are more informative in countries with higher quality earnings or better enforced insider trading laws, and that annual earnings announcements were less informative in countries with more frequent interim financial reporting. They also found that, on average, earnings announcements were more informative in countries with strong investor protection institutions.

Another research in France was done by Wael (2008) who analyzed intraday stock price changes on the Paris Stock Exchange. He managed to prove that investors reacted positively on positive earnings announcements and negatively on negative earnings announcements. He also pointed out that most of abnormal return disappeared within 15 minutes from the announcement and that the reaction was quicker for positive then for 
negative earnings announcements. Like Beaver he proved that trade volume also reacted on earning announcements.

The review of the existing literature has shown that most of the researches have been successful in proving their hypothesis that accounting variables announcement has information content and that the relationship between the earnings announcements and market variables really exists.

\section{RESEARCH DESIGN}

The Croatian stock exchange market called Zagrebačka burza (hereinafter ZSE) today has two stock indexes - CROBEX ${ }^{1}$ and CROBEX10 ${ }^{2}$. For the purpose of our research we have chosen the 10 stocks (Table 1) that are within CROBEX10 index as best representative for the CROBEX index and the whole capital market in Croatia.

Table 1 - Composition of CROBEX10

\begin{tabular}{|l|l|r|r|}
\hline \multicolumn{1}{|c|}{ Ticker } & \multicolumn{1}{|c|}{ Issuer } & \multicolumn{1}{c|}{$\begin{array}{c}\text { Free float } \\
\text { factor }\end{array}$} & \multicolumn{1}{c|}{$\begin{array}{c}\text { Number of } \\
\text { shares in } \\
\text { CROBEX10 }\end{array}$} \\
\hline ADRS-P-A & Adris grupa d. d. & $95 \%$ & 6.444 .895 \\
\hline ATPL-R-A & Atlantska plovidba d.d. & $80 \%$ & 1.116 .416 \\
\hline DLKV-R-A & Dalekovod d.d. & $85 \%$ & 1.949 .740 \\
\hline ERNT-R-A & $\begin{array}{l}\text { Ericsson Nikola Tesla } \\
\text { d.d. }\end{array}$ & $45 \%$ & 599.243 \\
\hline HT-R-A & HT d.d. & $50 \%$ & 6.098 .137 \\
\hline IGH-R-A & Institut IGH d.d. & $90 \%$ & 142.722 \\
\hline INA-R-A & Ina d.d. & $8 \%$ & 800.000 \\
\hline INGR-R-A & Ingra d.d. & Končar & 6.000 .000 \\
\hline KOEI-R-A & $\begin{array}{l}\text { elektroindustrija d.d. } \\
\text { PODR-R-A }\end{array}$ Podravka d.d. & $40 \%$ & 1.028 .848 \\
\hline
\end{tabular}

For the purpose of analysis we have decided to use the five years period from 2005 to 2009 due to data availability and since selected period covers years with strong growth, strong fall and stagnation of stock prices and trading volume. Since not all of the selected stocks were on the market during this period and some data were not available there were totally 46 stock/years observations included into the research sample. The data on stock prices and quantity of stocks traded and daily market index were collected from the website of $\mathrm{ZSE}^{3}$. Market data for each stock were collected from the May $15^{\text {th }}$ of the year for which the announcement was made until June $15^{\text {th }}$ of the year in which the annual earnings announcement was published. The data on the day of the announcements were also collected from ZSE. The analysis of capital markets reaction on published accounting information was done for the reporting period of 21 working days (10 days prior and 10 days after the announcement day).

Financial statements data required for the calculation of positive or negative change in earnings and operating cash flow was gathered from Reuter's database and from ZSE web site. The data for all the five years are shown in Table 2. To distinguish good (bad)

\footnotetext{
${ }^{1}$ ZSE share index comprised of 25 top ranked stocks by the market share

2 ZSE share index comprised of 10 top securities included into CROBEX index, with the largest free-float market capitalization and liquidity

${ }^{3}$ www.zse.hr
} 
announcement news we have decided to use naive model, where previous year published earnings/operating cash flows is forecast for next year earnings/operating cash flows. The announcement of accounting information represents good news if reported number is higher than in the previous year. Otherwise, if announced number is lower than in the previous year news is classified as bad.

Stock returns were calculated for all the stocks in all the years. Stock returns were calculated on the basis of the following equation: $R_{i, t}=\ln \left[\frac{P_{i, t}}{p_{i, t-1}}\right]$, where $\mathrm{P}_{\mathrm{i}, \mathrm{t}}$ is the price of stock $i$ in a day $t$. Dividends paid were not included in the calculation of returns because of several reasons but the most important one was that including dividends would influence significantly on the calculation of the abnormal stock returns. Namely, dividends are usually paid on only few days in a year and including them in the calculation of returns would significantly change the data for those few days and consequently the normal average returns during the non-reporting period.

If the earnings announcements convey information that is useful for investors then the magnitude of the price change should be larger on the accounting information announcement day in comparison with magnitude of the price change during the other days in the reporting period. The next step was calculating the market wide effect on each of the daily stock price returns. The model that we used to identify the market wide effects was CAPM, firstly used by Sharpe in 1963. The model for calculation of the expected daily stock price returns is based on the following equation: $\widehat{R}_{i, t}=a_{i}+b_{i} R_{M_{i}, t}+u_{i, t}$, where $\mathrm{R}_{i, t}$ is a measure of the price change of stock $i$ on day $t$, and $\mathrm{R}_{M, t}$ is stock index change on day $t$. All estimated CAPM models are shown in Table 3.

All the $b_{i}$ coefficients are significant at 5\% level, while most of the $a_{i}$ coefficients are not significant. It is not recommended to eliminate insignificant $a_{i}$ coefficients from the models because that could cause biased estimates or the overpriced value of the coefficients $b_{i}$. Surprisingly all of the D-W tests show a normal value (around 2), which means that there is no significant autocorrelation of residuals. 
Table 2 - Data for the period 2005-2009

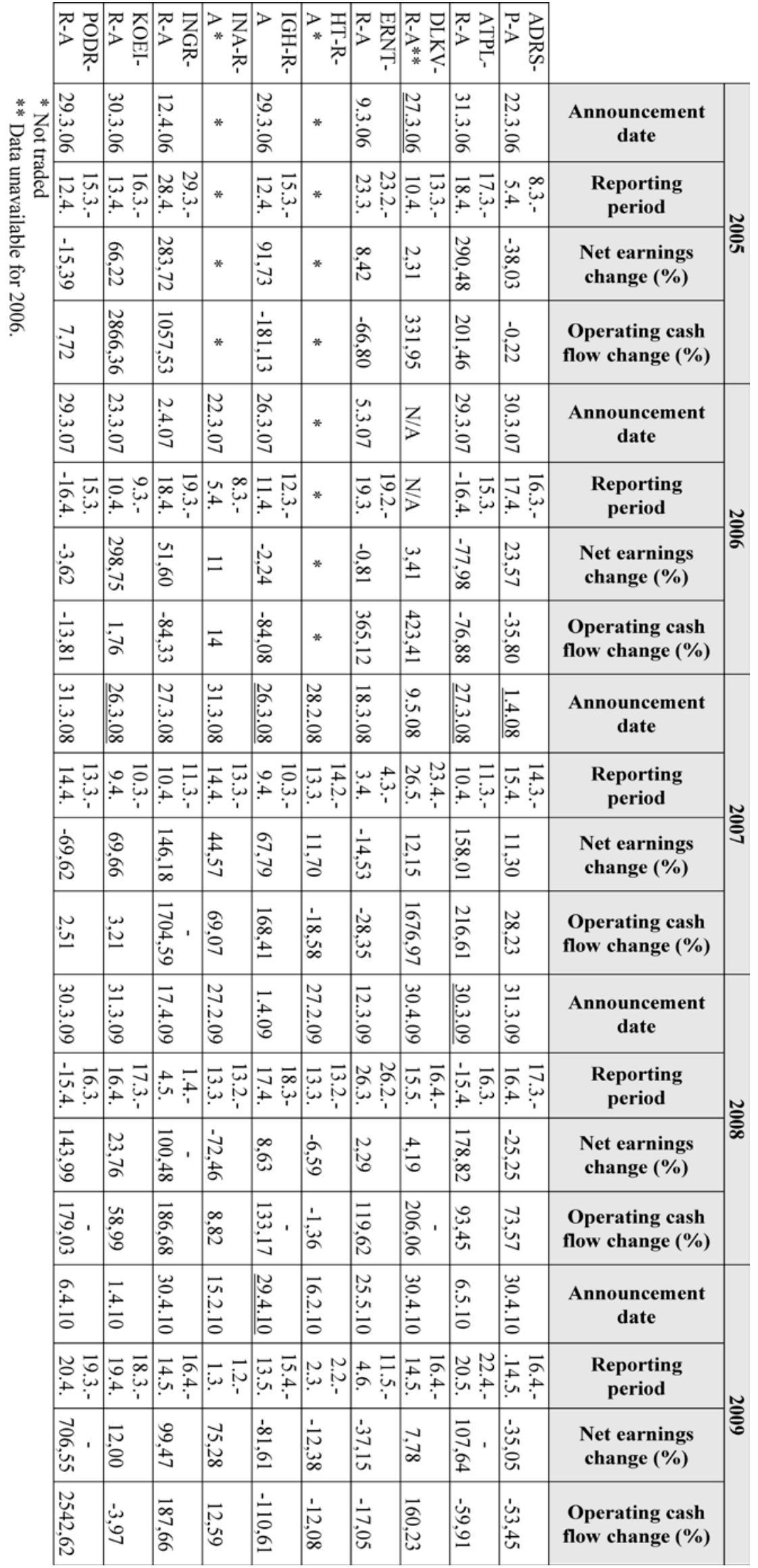


Table 3 - CAPM models

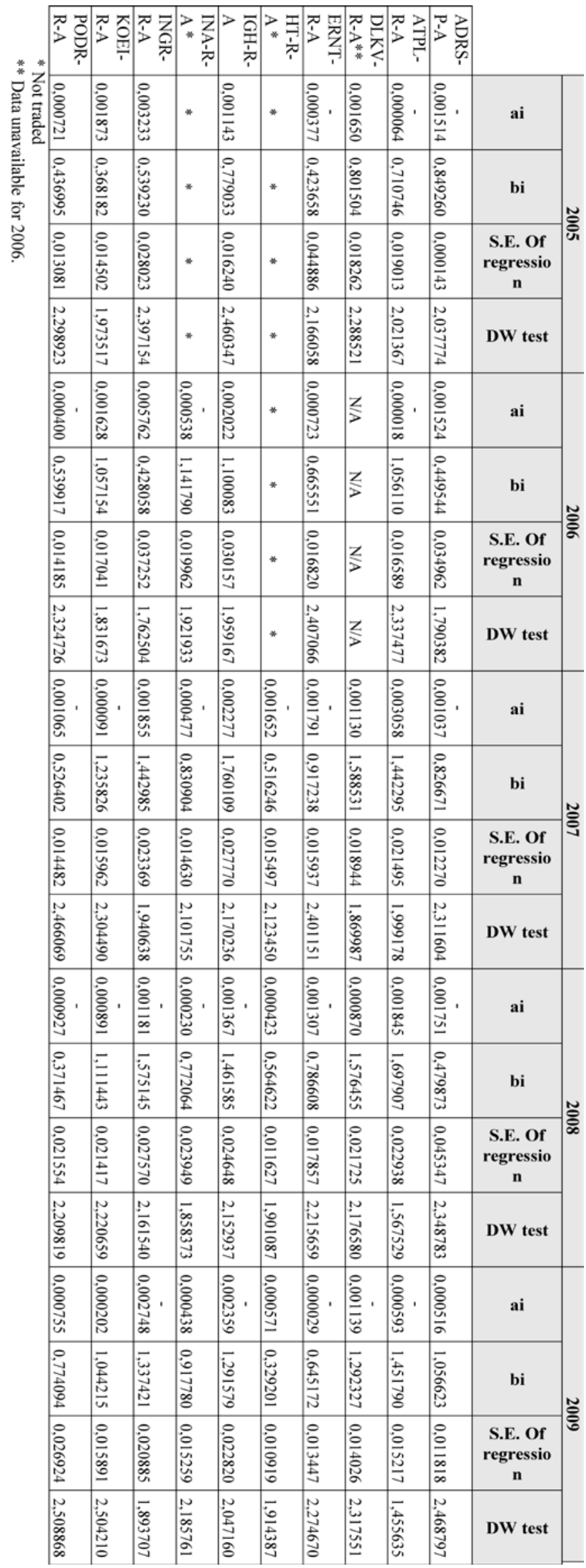


After forming all the CAPM models the abnormal returns for the reporting periods were calculated by using the following equation: $u_{i, t}=R_{i, t}-a_{i}-b_{i} R_{M_{i}, t}$. Since abnormal returns can be both positive and negative to avoid their mutual elimination all abnormal returns were squared $\left(\mathrm{u}_{\mathrm{i}, \mathrm{t}}{ }^{2}\right)$. Average value of $\mathrm{u}_{\mathrm{i}, \mathrm{t}}{ }^{2}$ in non-reporting period is in fact a variance of variable $u_{i, t}\left(s_{i}^{2}\right)$. Relation between residual $u_{i, t}^{2}$ for reporting period and $s_{i}^{2}$ for nonreporting period can be shown by ratio $U_{i, t}=\frac{u_{i, t}^{2}}{s_{i}^{2}}$. If the ratio is greater than 1 it means that there is return greater than usual, i.e. abnormal return.

Since using the constant variance $s_{i}^{2}$ for non-reporting period can cause overestimating of the results we have decided to use GARCH $(1,1)$ models to calculate the daily variance for the whole period of observation. Unexpected price changes can be overestimated when constant variance for non-reported period is assumed. In other words, the abnormal price activity is overestimated when the squared residual error is increasing within dynamic structure in comparison to the same variance of the fixed period. Therefore, GARCH $(1,1)$ models ${ }^{4}$ are used to estimate the conditional variance, i.e. time varying variance for each trading day according to the daily returns of the entire sample.

GARCH model uses the following estimation equation: $v_{i, t}^{2}=\alpha_{i}+\beta_{i, 1} R_{i, t-1}^{2}+\beta_{i, 2} v_{i, t-1}^{2}$, where $R_{i, t-1}^{2}$ is the squared return on the stock $i$ for the previous day $(t-1)$, and $v_{i, t-1}^{2}$ is volatility of returns for stock $i$ in for the previous day $(t-1)$. High values of parameters $\beta_{i, 1}$ and $\beta_{i, 2}$ indicate high persistence of volatility. Alternatively, if $\beta_{i, 1}+\beta_{i, 2}$ is close to 1 it means that long time is needed for volatility shocks to vanish. Based on the gathered variances the volatility of return was calculated by ratio $\mathrm{RVI}_{i, t}$ - return volatility index where $u_{i, t}^{2}$ is numerator and $v_{i, t}^{2}$ denominator. It is expected, if the initial assumptions on information content of accounting information from annual report (earnings and operating cash-flows) are correct, that the return volatility index - $\mathrm{RVI}_{i, t}$ will be significantly different from 1 in the period around the announcement.

\section{RESEARCH RESULTS}

The empirical analysis for 2005 has shown results as expected, since positive earnings and operating cash flows are followed by positive market reaction, while negative earnings and negative operating cash flows are followed by negative market reaction.

\footnotetext{
${ }^{4}$ GARCH models are mostly applied and developed in the field of finance, but can help to get closer insight whenever volatility is not constant over time (heteroskedasticity).
} 
Table 4: Return volatility index - RVI $\mathbf{I}_{\text {it }}-2005$

\begin{tabular}{|c|c|c|c|c|}
\hline $\begin{array}{c}\text { Reporting } \\
\text { period day }\end{array}$ & $\begin{array}{c}\text { Positive } \\
\text { earnings }\end{array}$ & $\begin{array}{c}\text { Positive } \\
\text { cash flow }\end{array}$ & $\begin{array}{c}\text { Negative } \\
\text { earnings }\end{array}$ & $\begin{array}{c}\text { Negative } \\
\text { cash flow }\end{array}$ \\
\hline-10 & 0.198 & 0.164 & -0.640 & -0.548 \\
\hline-9 & $\mathbf{2 . 1 7 4}$ & $\mathbf{1 . 8 7 7}$ & -0.360 & $\mathbf{- 1 . 4 6 0}$ \\
\hline-8 & $\mathbf{1 . 9 6 1}$ & $\mathbf{1 . 0 9 1}$ & $\mathbf{- 1 . 2 9 8}$ & $\mathbf{- 2 . 9 7 0}$ \\
\hline-7 & $\mathbf{1 . 0 5 1}$ & 0.834 & -0.363 & -0.953 \\
\hline-6 & 0.433 & 0.240 & -0.327 & -0.683 \\
\hline-5 & 0.752 & 0.254 & -0.192 & $\mathbf{- 1 . 2 1 0}$ \\
\hline-4 & 0.770 & 0.890 & $\mathbf{- 1 . 3 4 1}$ & -0.949 \\
\hline-3 & 0.153 & 0.181 & $\mathbf{- 2 . 2 8 4}$ & $\mathbf{- 1 . 5 2 7}$ \\
\hline-2 & 0.257 & 0.334 & $\mathbf{- 4 . 4 4 1}$ & $\mathbf{- 2 . 9 1 7}$ \\
\hline-1 & 0.729 & 0.624 & -0.170 & -0.533 \\
\hline 0 & 0.502 & 0.537 & $\mathbf{- 1 . 3 1 1}$ & -0.983 \\
\hline 1 & $\mathbf{3 . 0 7 2}$ & $\mathbf{2 . 3 0 2}$ & $\mathbf{- 2 . 7 0 0}$ & $\mathbf{- 4 . 1 0 7}$ \\
\hline 2 & $\mathbf{2 . 3 8 0}$ & 0.081 & -0.086 & $\mathbf{- 4 . 6 8 1}$ \\
\hline 3 & 0.845 & $\mathbf{1 . 1 1 5}$ & -0.378 & -0.084 \\
\hline 4 & $\mathbf{1 . 3 9 2}$ & $\mathbf{1 . 4 7 5}$ & -0.184 & -0.447 \\
\hline 5 & 0.788 & 0.876 & -0.114 & -0.191 \\
\hline 6 & 0.307 & 0.499 & $\mathbf{- 1 . 0 9 6}$ & -0.514 \\
\hline 7 & $\mathbf{1 . 6 2 0}$ & 0.570 & -0.020 & $-\mathbf{2 . 3 0 3}$ \\
\hline 8 & 0.567 & 0.816 & -0.856 & -0.346 \\
\hline 9 & 0.487 & 0.318 & -0.511 & -0.785 \\
\hline 10 & 0.181 & 0.191 & -0.287 & -0.235 \\
\hline
\end{tabular}

$\mathrm{RVI}_{i, t}$ indicates (Table 4 and Graph 2) that market has significant reaction (-1.311) for negative news on earnings on the day of announcement. One day after the announcement market reaction is observable for both accounting variables (earnings and operating cash flow) and both type of news (good and bad). Market reaction for both good and bad news can be followed even up to $7^{\text {th }}$ day after accounting information is published. This finding can lead to the conclusion that Croatian capital market in 2005 shows delayed reaction on published accounting information. But at the same time, we can also observe that positive and negative abnormal returns exist before the accounting information announcement, which might be the result of insider trading or other price sensitive information.

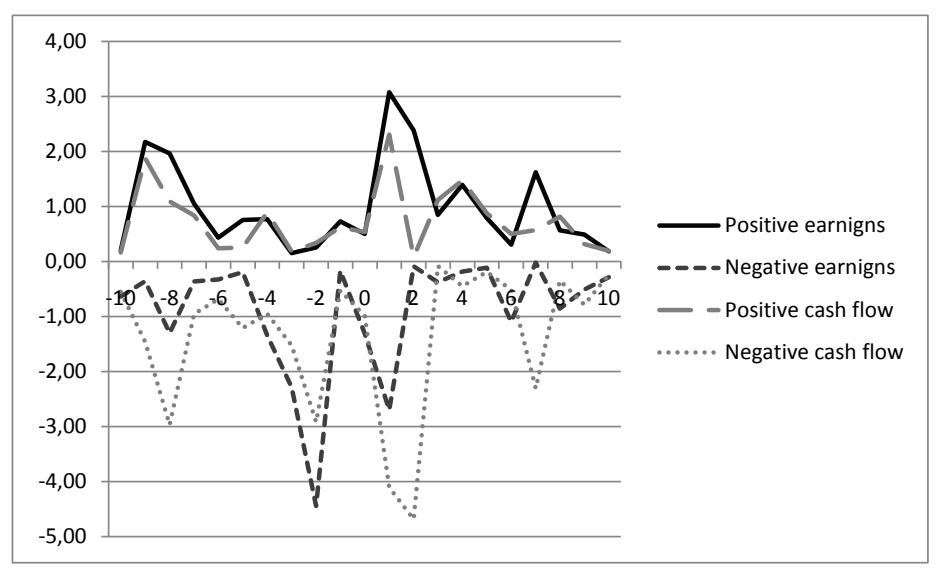

Graph 2 - RVI $\mathbf{I}_{i, t}$ for 2005 
Research results for all other years included in the analysis are shown on Graphs 3 to $6^{5}$. Graph 3 reveals that in 2006 market reacted on earnings and operating cash flows, that represented good and bad news on the day of information announcement. But it is also noticeable that market reaction can be observable for positive news until the seventh day after announcement, while for the bad news reaction ends after the ninth day. Movement of return volatility index in 2007 reveals strong market reaction on the announcement day for positive operating cash flow (2.979) and negative earnings (-9.542). Market reaction for positive earnings (1.220) is observable one day after the announcement while reaction for negative cash flow $(-2,672)$ is observed two days prior to the announcement.

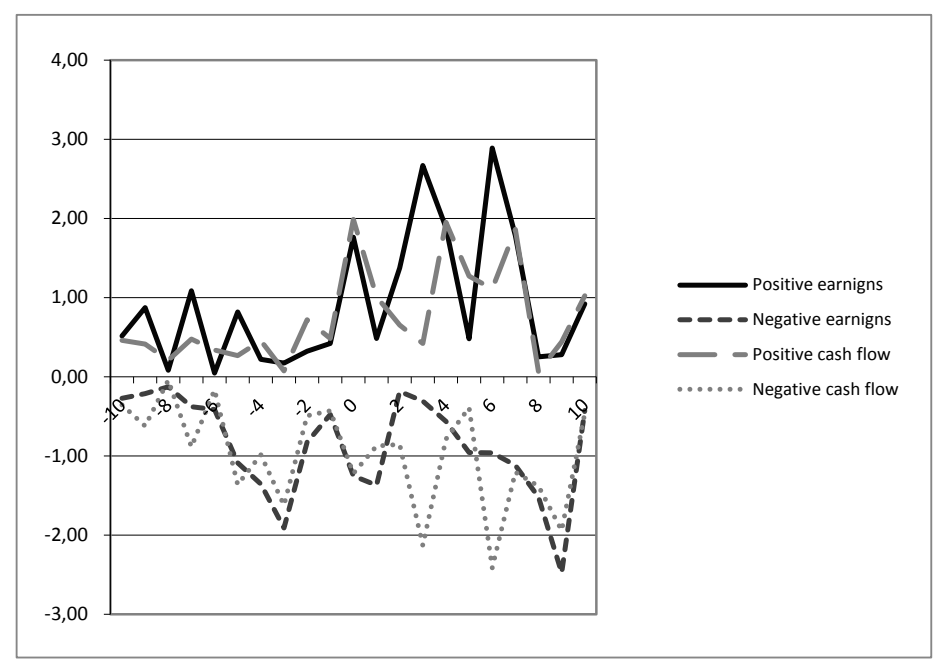

Graph 3 - RVI $\mathrm{R}_{i, t}$ for 2006

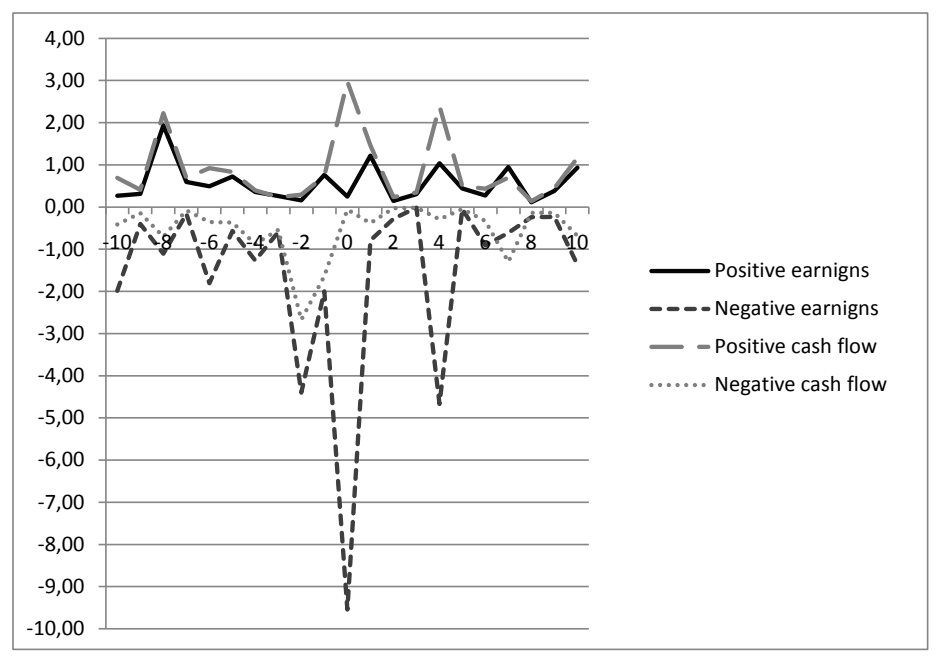

Graph 4 - RVI $\mathrm{R}_{i, t}$ for 2007

Year 2008 at ZSE was characterized by a strong fall of trade volume and stock prices due to the world financial crisis and pessimistic expectations about future results. Here we can notice that on the announcement day strong reaction exists for negative news, earnings (3.679) and operating cash flow (-3.542). Reaction for positive earnings is delayed and happens on the third day after announcement, while there is no reaction on negative operating cash flow after the announcement. However, here we must also notice that positive market

\footnotetext{
${ }^{5}$ Tables with detailed data on $\mathrm{RVI}_{\mathrm{it}}$ change in years 2006-2009 due to article space limitation are not presented but it can be obtained upon request.
} 
reactions for good news are observable three days before accounting information announcement.

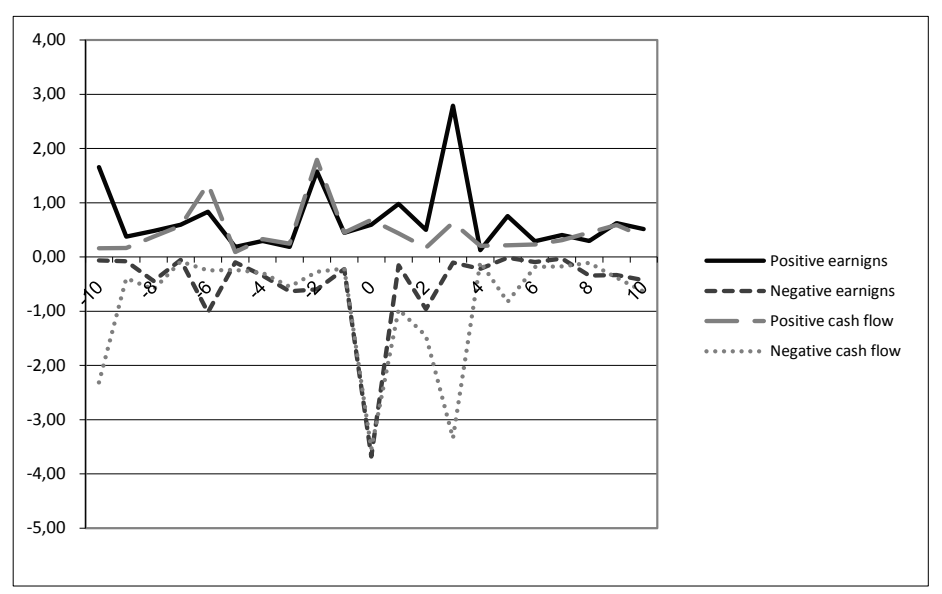

Graph 5 - RVI $\mathbf{I}_{i, t}$ f for 2008

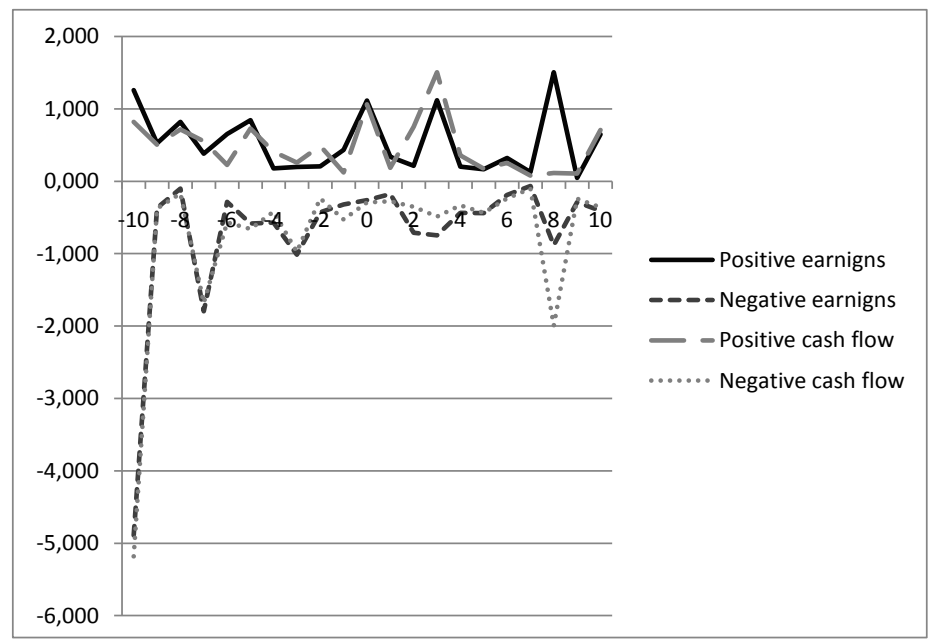

Graph 6 - RVI $\mathbf{I}_{i, t}$ for 2009

The final year included into analysis 2009 is characterized by certain recovery of share prices while trade volume at ZSE was modest. On the announcement day the market reacts only for good news, earnings (1.114) and operating cash flow (1.065), while there is no reaction to the bad news. Negative market reactions for bad news can be traced up to ten days before accounting information announcement. Findings for 2008 and 2009, years of strong fall and recovery, might indicate that capital market investors in years of bad economy put focus on bad news, while in years of economy recovery focus is on the good news.

\section{CONCLUDING REMARKS}

This research aimed to test the information content of accounting information (earnings and operating cash flow) from annual report in the context of investors' decisions at Zagreb Stock Exchange. We wanted to find out whether investors in Croatian emerging market environment use published accounting information from annual report, which is analyzed trough abnormal price changes around date of announcement. Therefore, the event study approach was adopted and we constructed the return volatility index $\mathrm{RVI}_{\mathrm{it}}$ in order to measure market reaction in period of 10 days before and after the announcement of accounting information. The constructed return volatility index has some advantages over similar indexes 
from previous studies since $\mathrm{RVI}_{\mathrm{it}}$ uses daily variance instead of constant variance when calculating abnormal returns in the nonreporting period.

As a general conclusion of research we can point out that both accounting performance measures from annual report, earnings and operating cash flow, have information content since the market reacts on published information with abnormal returns. Abnormal returns reaction exists both for good and bad news, where good news are followed by positive abnormal returns, while the bad news are followed by negative abnormal returns. Market reaction on the announcement day and one day after announcement is observed in almost all years included into analysis. Also, $\mathrm{RVI}_{\mathrm{it}}$ movement indicates that Croatian capital market might have delayed reaction on published information since abnormal returns can be traced even up to 10 days after the annual report announcement at ZSE.

As limitation of the study we could point out a relatively small sample and some future studies could try to explore the same issue on a larger sample. Also, empirical findings indicate that significant abnormal returns exist before and after the day of annual report announcement, which can be explained by market inefficiency or insider trading. But, since we did not have a very detailed data-base on other price sensitive information (take-over announcement, new contract, new product, entering the new market, R\&D success or failure, etc.) any conclusion about causes of abnormal returns before and after the announcement day is not completely reliable.

\section{REFERENCES:}

Ball, R., Brown, P., (1968), "An Empirical Evaluation of Accounting Income Numbers", Journal of Accounting Research, August: 159-178.

Beaver, W., H., (1968): "The Information Content of Annual Earnings Announcements", Empirical Research in Accounting: Selected Studies, Supplement to Journal of Accounting Research, 6: 67-92.

DeFond, M., Hung, M., Trezevant, R., (2007): "Investor protection and the information content of annual earnings announcements: International evidence", Journal of Accounting and Economics, 43 (1): 37-67.

Gajewski, J-F, Quere, P., B., (2001): "The information content of earnings and turnover announcements in France", The European Accounting Review, 10 (4): 679-704.

IASB, (2008): International Financial Reporting standards (IFRSs) 2008, (London: IASCF).

Lewis, R., Pendrill, D., (2004): Advanced Financial Accounting, (Harlow: Prentice Hall).

Morse, D., (1981): "Price and Trading Volume Reaction Surrounding Earnings Announcements: A Closer Examination", Journal of Accounting Research, 19 (2): 374383.

Patell, J., Wolfson, M., (1984): "The intraday speed of adjustment of stock prices to earnings and dividend announcements", Journal of Financial Economics, 13 (82): 223-252.

Pervan, I., (2006): "Dobrovoljno financijsko izvješćivanje na Internetu-analiza prakse hrvatskih i slovenskih dioničkih društava koja kotiraju na burzama" Financijska teorija i praksa, 30 (1): 1-27.

Pervan, I., (2009): "Korporativno izvještavanje u Hrvatskoj - analiza stanja i mogućnosti za unaprjeđenje regulative i prakse", chapter in book Računovodstveno izvještavanje u RH $i$ harmonizacija sa zahtjevima EU, (Split: Ekonomski fakultet).

Vafeas, N., Trigeorgis, L., Georgiou, X., (1998): "The usefulness of earnings in explaining stock returns in an emerging market: the case of Cyprus", The European Accounting Review, 7 (1): 105-124. 
Wael, L., (2008): "Adjustment of stock prices to earnings announcements: evidence from Euronext Paris", Review of Accounting and Finance, 7 (1): 102-115.

White, G., I., Sondhi, A., C., Fried, D., (1997): The Analysis and use of Financial Statements, (New York: John Wiley \& Sons).

\title{
INFORMACIJSKI SADRŽAJ DOBITI I OPERATIVNOG NOVČANOG TIJEKA IZ GODIŠNJIH IZVJEŠTAJA -ANALIZA ZA HRVATSKA LISTANA DRUŠTVA
}

\begin{abstract}
SAŽETAK
Osnovni cilj ovog istraživanja je testiranje informacijskog sadržaja računovodstvenih informacija (dobiti i operativnog novčanog toka) u kontekstu ulagačkih odluka na tržištu kapitala. Istraživanje je bazirano na pristupu "studije događaja", gdje je indeks volatilnosti povrata dionica $R V I_{i t}$ korišten za mjerenje reakcije tržišta u razdoblju od 10 dana prije $i$ nakon na objave računovodstvenih informacija. Istraživanje je provedeno na uzorku kompanija iz indeksa CROBEX 10, tj. na uzorku 10 najtrgovanijih kompanija sa Zagrebačke burze u razdoblju od 2005 do 2009 godine. Kao opći zaključak istraživanja može se navesti da računovodstvene informacije iz godišnjih izvještaja (dobit i operativni novčani tok) imaju informacijski sadržaj jer tržište reagira na objavu informacija kroz abnormalne povrate.
\end{abstract}

Ključne riječi: dobit, operativni novčani tok, informacijski sadržaj, povrat dionica 